\author{
Krzysztof ZIELECKI ${ }^{1}$ \\ Lucjan WITEK ${ }^{2}$ \\ Feliks STACHOWICZ ${ }^{3}$
}

\title{
STRESS ANALYSIS OF THE SINGLE ADHESIVE LAP JOINTS WITH PLASTIC DEFORMATION OF CONNECTED MATERIALS
}

\begin{abstract}
In this work the results of numerical stress analysis of single adhesive lap joints were presented. In the analysis both the linear-elastic and the elastic-plastic models of adherends materials were considered. Plastic deformation of adherends has a significant influence on the stress state in the adhesive layer. In the first part of the work the mechanical properties of adherends material obtained in experimental investigations were presented. In next part of the study the numerical model of joint was presented. The results of static analysis using the finite element method showed that in the case of joining materials with low value of yield stress the plastic deformation occurs in adherend at load much smaller than destructive force of the joint. In this kind of joints the plastic deformation of adherend has an influence on rapid stress increase in adhesive layer, in final stage of loading. This phenomenon causes a decrease of load capacity of single adhesive lap joints of elasticplastic materials.
\end{abstract}

Keywords: single adhesive lap joint, stress analysis, finite element method, plastic strain

\section{Introduction}

Design of products may require the usage of inseparable joints. It can be realized by adhesive joints, where materials are connected by an adhesive layer. These joints are used for example in aircraft and automotive industry. The advantage of adhesive joints is continuous load transfer without stress concentrations in comparison to e.g. welded, projection welded, riveted joints.

Adhesively bonded joints can transfer lower loads than above mentioned [1] but in some cases they are only the one option. For example in case of necessity of joining very thin materials. Other application example would be joint

\footnotetext{
${ }^{1}$ Krzysztof Zielecki, ZF Friedrichshafen AG, Schweinfurt, Germany, e-mail: kzielecki@ yahoo.com

2 Autor do korespondencji/corresponding author: Lucjan Witek, Rzeszow University of Technology, 12 Powstańców Warszawy Ave., 35-959 Rzeszów, Poland, e-mail: lwitek@prz.edu.pl

${ }^{3}$ Feliks Stachowicz, Rzeszow University of Technology, e-mail: stafel@ prz.edu.pl
} 
of different materials, which cannot be welded [2-4]. Damping properties of adhesive joints might also be considered as an advantage [5]. Designers work continuously in order to increase the strength of bonded joints. One of the approach to increase the strength is decreasing of joint stiffness in the external area of overlap by changing the geometrical parameters [6-9]. An engineering tool which allows the stress analysis of adhesive joints is finite element method (FEM) [10-14]. Most of research works are related to the analysis of joints with linear-elastic material of adherends.

The main aim of this work is numerical determination of stress state in single adhesive lap joints with elastic-plastic model of adherend material. In order to make a comparative analysis, the joint with linear-elastic model of material will be also considered.

\section{Numerical model of joint and the boundary conditions}

The joint (Fig. 1) was composed of two sheets (dimensions: $100 \times 25 \times 2 \mathrm{~mm}$ ) made out of S185 carbon steel. The sheets were connected using Araldite 2014-1 epoxy adhesive. The thickness of adhesive layer equals $0.2 \mathrm{~mm}$. The adhesive was modeled as linear-elastic material. The joint was loaded by the force $\mathrm{F}=5282 \mathrm{~N}$ (destructive force obtained in experimental investigations). In this study two kinds of model of joined materials (adherends) were considered.

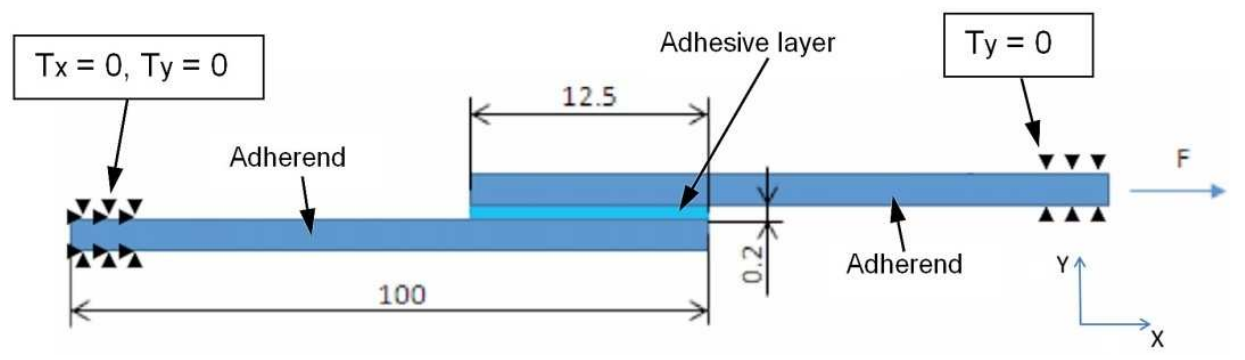

Fig. 1. Dimensions, boundary conditions and load of joint

The numerical model of joint is composed of 134589 QUAD-8 finite elements [15] with quadratic shape function and 406706 nodes. The finite element mesh was concentrated in the border zone of adhesive layer. In the numerical analysis the plain strain was considered in order to determine the stress state in the central section of the joint. The simplification of the analysis to plain strain. decreases the size of the numerical task. The set of nodes located on the left part of the joint (Fig. 2) was fixed (translations: $T_{x}=0, T_{y}=0$ ). For nodes located on the right part of the joint the partial fixation was defined $\left(\mathrm{T}_{\mathrm{y}}=0\right)$. These boundary conditions are equivalent to the conditions occurring in the experimental tension test of the joint. The force $\mathrm{F}=5282 \mathrm{~N}$ was defined on the right border surface of the model. This load was equal to the destructive force of the joint. 


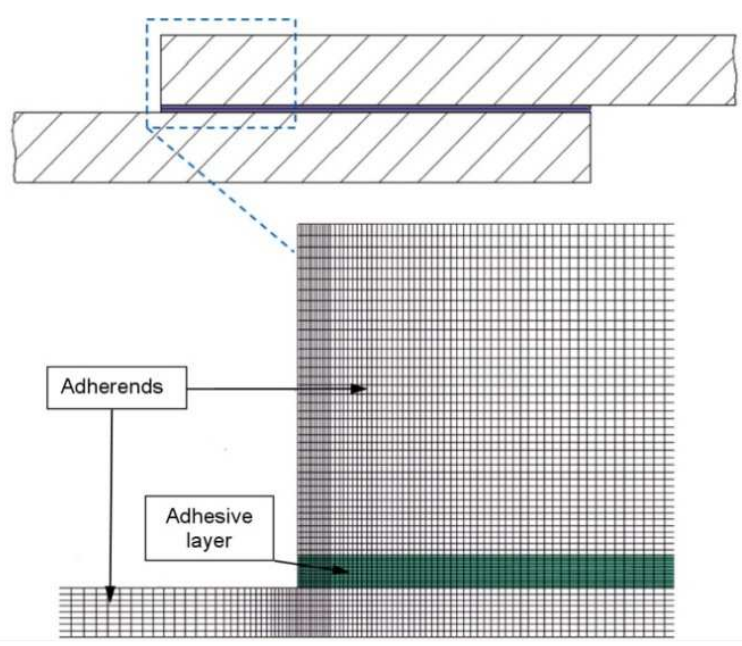

Fig. 2. Fragment of numerical model of joint with finite element mesh

\section{Experimental material tests of adhesive and adherend}

Single adhesive lap joints were made using the Araldite 2014-1 adhesive (Huntsman Advanced Materials GmbH Company). Araldite 2014-1 is two components epoxy adhesive used for connection of metal structures. The adhesive is delivered in two containers (adhesive and hardener, proportion 2:1). The adhesive was mixed using a screw mixing nozzle. In order to determine the mechanical properties of the Araldite 2014-1 adhesive, the flat specimens with the use of casting method were first prepared. The specimens were next subjected to the static tension test. The results of the tension test performed for two specimens are presented in Fig. 3.

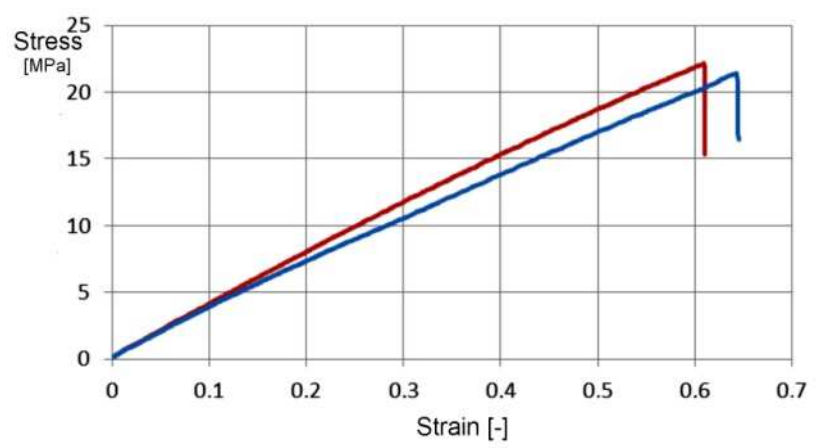

Fig. 3. Stress-strain characteristics for Araldite 2014 adhesive after hardening 
On the base of performed experimental investigations the following mechanical properties of Araldite 2014-1 adhesive were specified: Young's modulus $\mathrm{E}=3425 \mathrm{MPa}$, ultimate tensile strength UTS $=21.8 \mathrm{MPa}$. Obtained results (Fig. 3) show that Araldite 2014-1 adhesive after hardening can be considered as linear-elastic material. The adherends were made out of S185 carbon steel [16]. In order to determine the material characteristics of S185 steel the specimens were subjected to experimental investigations. The result of the static tension test of adherend material is presented in Table 1.

The tension test of S185 steel (plot of stress vs. strain) does not take into account the cross-section changes during tension of the specimen. In order to define the elastic-plastic model of material (according to Abaqus solver requirements [15]) there is a need to determine both the Young's modulus and also the plot of real stress vs. plastic strain. This plot is presented in Fig. 4. The results of material investigations showed that S185 steel has the yield stress value of $163 \mathrm{MPa}$. The ultimate tensile strength (UTS) of this steel equals $304 \mathrm{MPa}$ (Tab. 1).

Table 1. Mechanical properties of S185 steel

\begin{tabular}{|c|c|c|}
\hline $\begin{array}{c}\text { Young's modulus } \\
\text { E }[\mathrm{MPa}]\end{array}$ & $\begin{array}{c}\text { Yield stress } \\
\mathrm{R}_{0,2}[\mathrm{MPa}]\end{array}$ & $\begin{array}{c}\text { Ultimate tensile strength } \\
\text { UTS }[\mathrm{MPa}]\end{array}$ \\
\hline 209600 & 163 & 304 \\
\hline
\end{tabular}

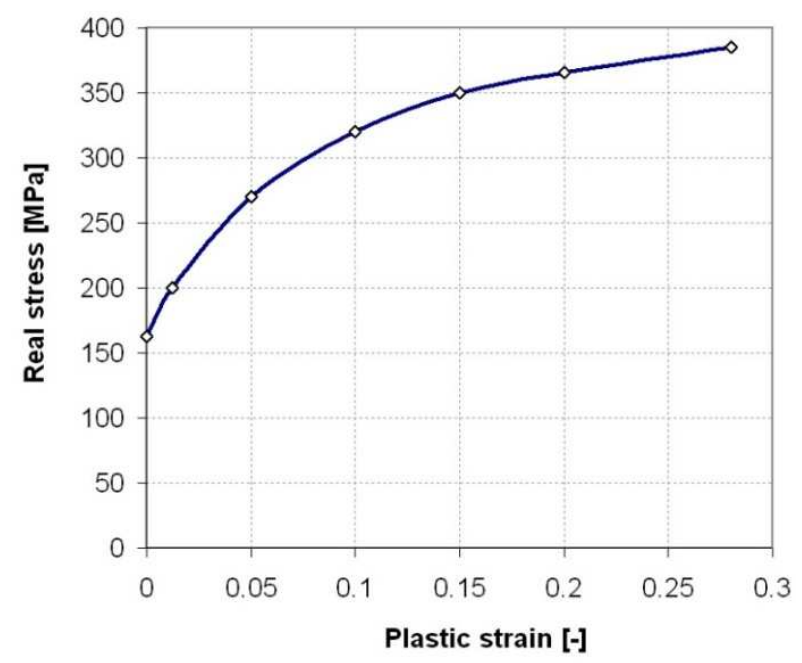

Fig. 4. Plot of real stress vs. plastic strain for S185 steel used for definition of elastic-plastic model of adherend material 


\section{Stress and strain analysis of adhesive joints}

In the results of numerical calculations using finite element method the stress distributions were obtained for single adhesive lap joints, for two following configurations:

a) Linear-elastic model of adherend material (S185 steel) described by the Young's modulus (209.6 GPa) and the Poisson's ratio (0.3), linear analysis.

b) Elastic-plastic model of adherend material, described by the Young's modulus and the real stress vs. plastic strain characteristic (Fig. 4), nonlinear analysis.

In Fig. 5 the stress distribution for the joint with linear-elastic model of adherend material is presented. As can be seen in this figure the largest equivalent stress (calculated for destructive force $\mathrm{F}=5282 \mathrm{~N}$ ) has a value of $473.42 \mathrm{MPa}$. The largest stress area occurs in the sheets, just near the end of the adhesive layer. Obtained results show that equivalent stress is about 3 times larger than the yield stress of S185 steel (163 MPa). The conclusion is that the stress distribution computed for considered joint (with linear-elastic model of adherend material) could not be real.
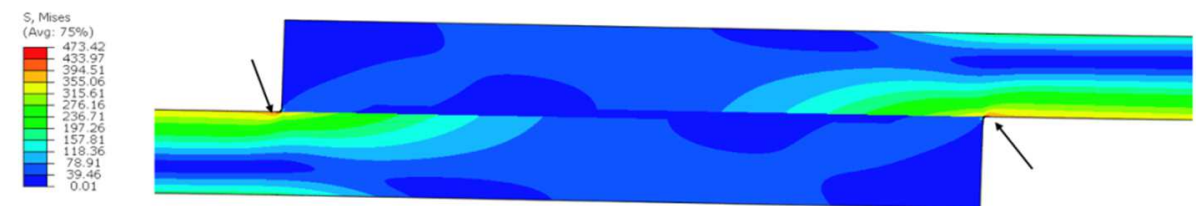

Fig. 5. Equivalent stress distribution (according to Huber-Mises-Hencky criterion) for central part of the joint. Results of nonlinear stress analysis for joint with linear-elastic model of adherend material, for load $\mathrm{F}=5282 \mathrm{~N}$ )

In Fig. 6 the result of nonlinear stress analysis of joint with elastic-plastic model of adherend material is presented. It is visible that after using the elasticplastic model of material the maximum equivalent stress (according to HuberMises-Hencky (H-M-H) criterion) in sheets was reduced to the value of 230 $\mathrm{MPa}$. This value exceeds the yield stress of S185 steel. It means that the material of sheets was strengthened. Zone of maximum stress area is located on the surface of sheet, near the end of adhesive layer.

As can be seen in Fig. 6 the complex stress state occurs in the joint. The sheets are subjected to both the tension and the bending (related to non-axial load of the lap joint). After plastifying adherend (sheets) the bending state is increased what causes larger deformation of the joint. 

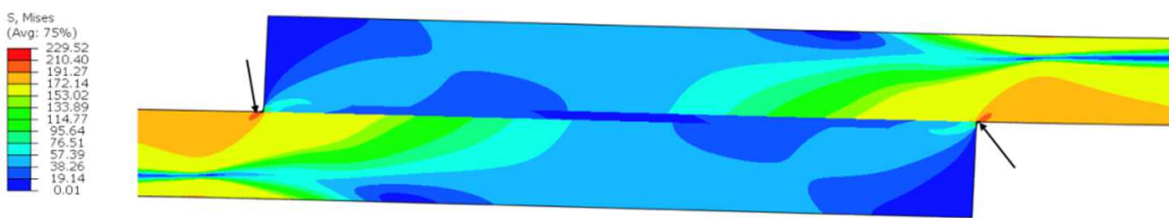

Fig. 6. Equivalent (H-M-H) stress distribution for central part of the joint. Results of linear stress analysis for joint with elastic-plastic model of adherend material, for load $\mathrm{F}=5282 \mathrm{~N}$ )

In Fig. 7 the plastic strain distribution in adherends is presented. From this figure it is visible that the plastic strain area achieves more than $50 \%$ of the sheet cross-section area. The largest plastic strain zones (points A1, Fig. 7) are located on the sheet surface, about $0.2 \mathrm{~mm}$ outside of the adhesive layer. The plastic strain zones begin in sheets, on the border of adherend-adhesive layer (points B1).
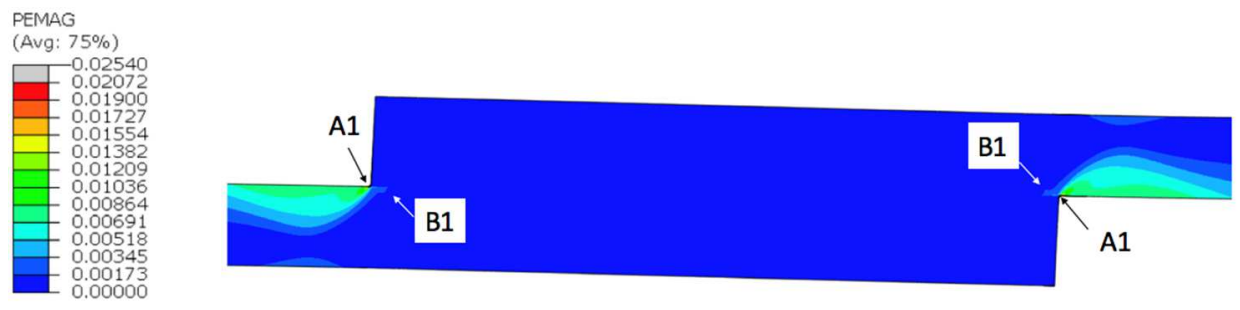

Fig. 7. Plastic strain distribution in the joint loaded by force $\mathrm{F}=5282 \mathrm{~N}$

The results presented above were related to the stress in the sheets (adherends). But the destructive force in adhesive joints depends mainly on stress levels in the adhesive layer. In next part of the study the stress in adhesive layer will be analyzed.

In Fig. 8 the joint section is presented. In this figure the $X$ axis is located in the adhesive layer, in distance of $0.02 \mathrm{~mm}$ from the adhesive-adherend border. The $\mathrm{X}$ axis ( $\mathrm{X}$ coordinate) will be used for description of horizontal axis of the plot presented in Fig. 9. The $X$ axis location was defined on the base of experimental results (the cohesive fracture of the adhesive layer was located in distance of $0.02 \mathrm{~mm}$ from the adhesive-adherend border).

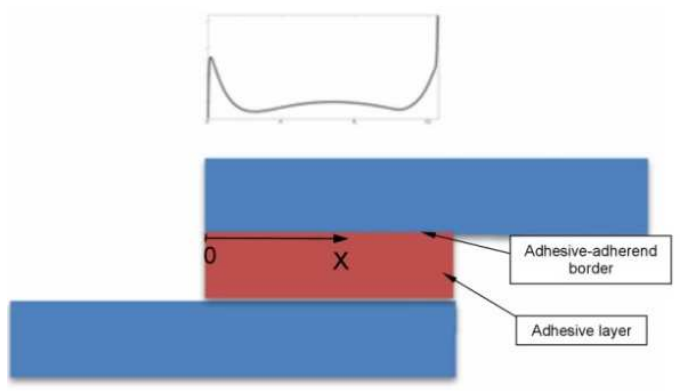

Fig. 8. Location of $\mathrm{X}$ axis used for description of horizontal axis of plot presented in Fig. 9 
In Fig. 9 the maximum principal $\left(\sigma_{1}\right)$ stress values as a function of $\mathrm{X}$ coordinate is presented. Value 0 of $X$ coordinate is defined for the beginning of the adhesive layer. The $\sigma_{1}$ stress distribution (common with the tearing and the shear stresses [7]) has the largest influence on strength of single adhesive lap joints.

As can be seen in Fig. 9 in the left part of adhesive layer (for linear-elastic model of adherend material) the $\sigma_{1}$ stress has a value of $71 \mathrm{MPa}$. The area of maximum stress is located in the adhesive layer on coordinate $X=0.3 \mathrm{~mm}$. After the use of the elastic-plastic model of adherend material the $\sigma_{1}$ stress in the adhesive layer has a value of $80 \mathrm{MPa}$. In the central part of the adhesive layer the stresses in adhesive layer for both models of materials have a value of about 8-10 MPa.

A larger difference in stress values is observed in the right part of the adhesive layer. In this zone the $\sigma_{1}$ stress has a value of $175 \mathrm{MPa}$ (for linear-elastic model of adherend material) and $240 \mathrm{MPa}$ (for elastic-plastic model of material). Observed large stress increasing in adhesive layer is related to the plastic deformation of adherends (joined sheets).

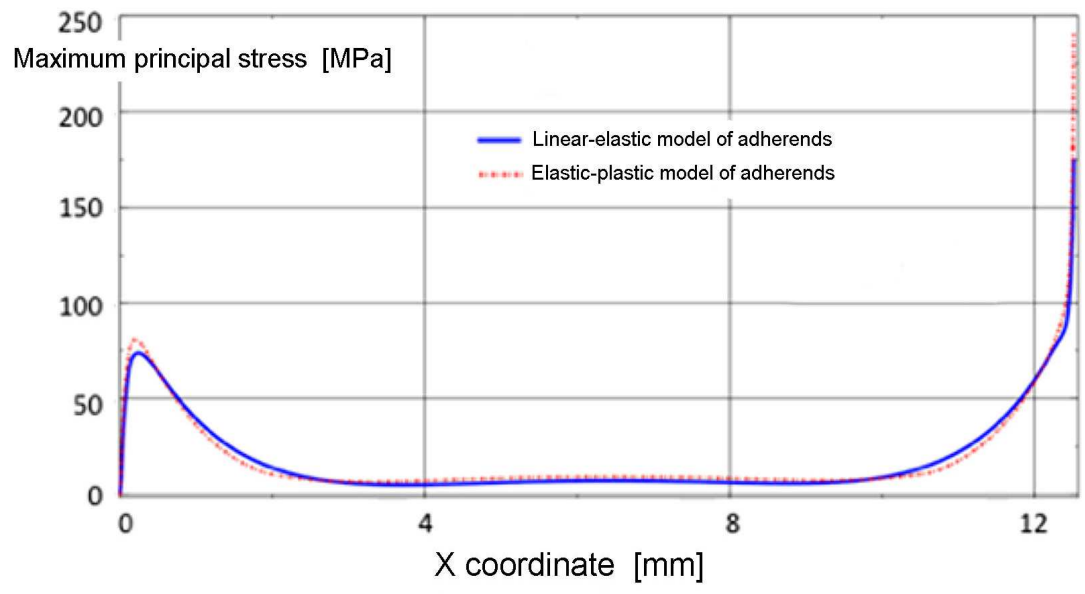

Fig. 9. Maximum principal $\left(\sigma_{1}\right)$ stress values as a function of $X$ coordinate in adhesive layer for linear-elastic and elastic-plastic model of adherend material

The material of sheets was considered (in second case) as elastic-plastic. From this reason in this work the nonlinear static analysis was used [15]. In computations the load $\mathrm{F}=5282 \mathrm{~N}$ was divided onto smaller increments. In the analysis the constant increment (step time) of 0.1 was defined. As a result of computations (for first increment, step time of 0.1) the stress state was obtained for the load which is equal to $10 \%$ of destructive force. During next increments the load is increased. The analysis is finished if the step time equals 1.

In Fig. 10 the maximum shear stress values in the adhesive layer as a function of step time is showed. Step time value of 1 should be related to the force of $\mathrm{F}=5282 \mathrm{~N}$. 
From Fig. 10 it is seen that (for linear-elastic material of adherends) a linear increase of shear stress in adhesive layer is observed. The different character has a curve defined for elastic-plastic model of adherend materials. In this case the stress in the adhesive layer is proportional to the load, to the step time of 0.5 only. At higher values of step time the progressive increase of stress is observed. It means that the first plastic strain occurs in adherends (made out of S185 steel) at load of $2641 \mathrm{~N}$ which is equivalent to $50 \%$ of joint destructive force.

The quantitative results of experimental investigations of adhesive lap joints showed that the components of the joint after destructive test occur the permanent deformations. These deformations are visible after fracture of the joint (Fig. 11).

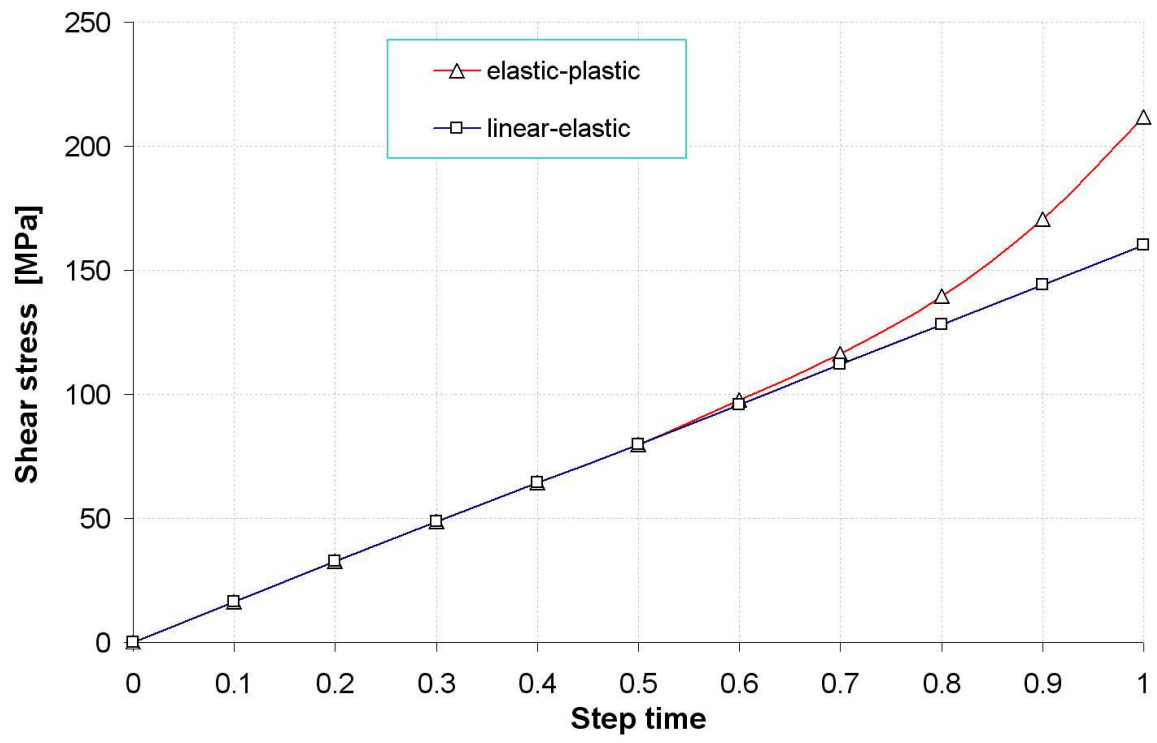

Fig. 10. Maximum values of shear stress in adhesive layer as a function of step time. Step time of 1 is equal to $\mathrm{F}=5282 \mathrm{~N}$

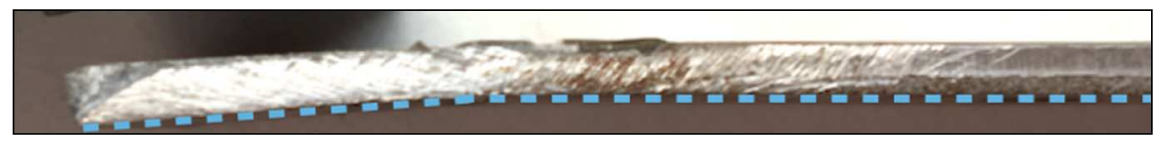

Fig. 11. Segment of adhesive joint (adherend) after destructive test. The permanent deformation of sheet is visible

\section{Conclusions}

In this work the results of stress analysis of single adhesive lap joints were presented. For adherends two following models of material were defined: linearelastic and the elastic-plastic. In the results of numerical finite element analysis 
both the stress and the plastic strain were calculated for the joint components. Using the nonlinear static analysis the shear stress in the adhesive layer as a function of time step was additionally determined. On the basis of realized study the following conclusions can be formulated:

1. The maximum equivalent stress in joined sheets (for linear elastic model of adherends material) has a value of $473.42 \mathrm{MPa}$. This stress exceeds about 3 times the yield stress of S185 steel.

2. In the joint with elastic-plastic model of adherend material the maximum stress in the sheets achieves the value of $230 \mathrm{MPa}$.

3. Plasticisation of material of bonded sheets causes their larger deformation in the vicinity of edge of the adhesive layer. As a result, at loads larger than $50 \%$ of destructive force a rapid stress increase is observed in the adhesive layer.

4. In presented case, the use of elastic-plastic model of adherend material caused increase the maximum stress in adhesive layer at about 37\% (in comparison to the joint with linear-elastic model of adherend material).

5. In joints of materials with low value of yield stress the elastic-plastic model of adherend materials should be used in order to correct stress estimation in the adhesive layer.

\section{Acknowledgement}

The research leading to these results has received funding from the People Programme (Marie Curie International Research Staff Exchange) of the European Union's Seventh Framework Programme FP7/2007-2013/ under REA grant: PIRSES-GA-2013-610547.

\section{References}

[1] Biruk-Urban K., Kuczmaszewski J.: Modyfikacja klejów epoksydowych w aspekcie ich właściwości cieplnych, Technologia Automatyzacja Montażu, 2 (2013) 31-34.

[2] Petrie E.M.: Handbook of Adhesives and Sealants, McGraw - Hill Professional, New York, 2006.

[3] Habenicht G.: Kleben erfolgreich und fehlerfrei: Handwerk, Praktiker, Ausbildung, Industrie, Wiesbaden, Vieweg+Teubner, 2008.

[4] Habenicht G.: Kleben - Grundlagen, Technologien, Anwendungen, Berlin, Springer 2008.

[5] Pocius. A.V.: Adhesion and Adhesives Technology: An Introduction, Cincinnati Carl Hanser Verlag GmbH Co KG, 2012.

[6] Verein Deutscher Ingenieure: VDI 2229 Metallkleben, Metallkleben Hinweise für die Konstruktion und Fertigung, VDI-Gesellschaft für Konstruktion und Entwicklung, 1979.

[7] Kuczmaszewski J.: Fundamentals of metal-metal adhesive joint design, Lublin University of Technology, Polish Academy of Sciences, 2006. 
[8] Yana Z.M., Youa M., Yib X.Y., Zhenga X.L. , Lia Z.: A numerical study of parallel slot in adherend on the stress distribution in adhesively bonded aluminum single lap joint, Int. J. Adhesion Adhesives, 27 (2007) 687-695.

[9] Pires I., Quintino L., Durodola J.F., Beevers A.: Performance of bi-adhesive bonded aluminium lap joints, International Journal of Adhesion \& Adhesives 23 (2003) 215-223.

[10] Godzimirski J., Rośkowicz M., Tkaczuk S.: Wytrzymałość połączeń klejowych, WAT, Warszawa 2010.

[11] Hua Y., Gu L., Trogdon M.: Three-dimensional modeling of carbon/epoxy to titanium single-lap joints with variable adhesive recess length, Int. J. Adhesion Adhesives, 38 (2012) 25-30.

[12] Xiaocong H.: A review of finite element analysis of adhesively bonded joints, Int. J. Adhesion Adhesives, 31 (2011) 248-264.

[13] Zielecki K., Witek L.: Influence of young modulus of connected materials on ultimate strength of beveled adhesive joints, Proc. Int. Conf. Advances in Micromechanics of Materials, Rzeszów 2014.

[14] Zielecki K., Witek L.: Analysis of stress and ultimate strength of modified single adhesive lap joints, Logistyka, 4 (2015) 7015-7021.

[15] ABAQUS Users Manual, Abaqus Inc., 2009.

[16] http://www.salzgitterstahlhandel.pl/pl/produkty/gatunki_normy/gatunki_ EN10025.

\title{
ANALIZA NAPRĘŻEŃ JEDNOZAKŁADKOWYCH POŁĄCZEŃ KLEJOWYCH Z PLASTYCZNYM ODKSZTALCENIEM LĄCZONYCH MATERIAŁÓW
}

\begin{abstract}
Streszczenie
W pracy przedstawiono wyniki numerycznej analizy naprężeń jednozakładkowych połączeń klejowych. Dla łączonych blach zastosowano dwa modele materiału: liniowo-sprężysty oraz sprężysto-plastyczny. Odkształcenie plastyczne materiału klejonego wywiera znaczący wpływ na stan naprężeń $\mathrm{w}$ warstwie kleju. W pierwszej części pracy przedstawiono właściwości mechaniczne materiału łączonego, które otrzymano w badaniach eksperymentalnych. W następnej części pracy przedstawiono model numeryczny połączenia. Wyniki analizy statycznej metodą elementów skończonych wykazały, że w przypadku łączenia materiałów charakteryzujących się niską wartością granicy plastyczności odkształcenie plastyczne występuje w materiale łączonym przy obciążeniu znacznie mniejszym od siły niszczącej połączenie. Zjawisko to powoduje obniżenie nośności jednozakładkowych połączeń klejowych materiałów sprężysto-plastycznych.
\end{abstract}

Słowa kluczowe: zakładkowe połączenie klejowe, analiza naprężeń, metoda elementów skończonych, odkształcenie plastyczne

DOI: $10.7862 / \mathrm{rm} .2017 .22$

Otrzymano/received: 24.05 .2017

Zaakceptowano/accepted: 21/06.2017 